\title{
PReS-FINAL-2031: Hyaluronic acid is a marker of active arthritis, but not systemic inflammation in systemic juvenile idiopathic arthritis
}

\author{
B Hugle ${ }^{1 *}$, M Olsson², N Fischer ${ }^{1}$, M Herrmann $^{3}$, K Lindblad-Toh², JP Haas $^{1}$ \\ From 20th Pediatric Rheumatology European Society (PReS) Congress \\ Ljubljana, Slovenia. 25-29 September 2013
}

\section{Introduction}

Systemic juvenile idiopathic arthritis (JIA) is a subtype of childhood arthritis associated with significant systemic inflammation as well as arthritis. Hyaluronic acid as a constituent of connective tissue has previously been described as a marker for arthritis in JIA in an Asian population. Mutations in hyaluronic acid synthase 2 leading to accumulation of hyaluronic acid have been found to be associated with a periodic fever syndrome in Shar-Pei dogs. Hyaluronic acid has therefore been suspected as a risk factor for systemic inflammation in humans.

\section{Objectives}

To investigate the correlation of hyaluronic acid levels with clinical manifestations and markers of inflammation in patients with systemic juvenile idiopathic arthritis.

\section{Methods}

Patient sera and clinical data were acquired from the AIDnet database, a German database and biobank where samples from patients with inflammatory syndromes including periodic fevers syndromes and systemic JIA are collected prospectively. A single center sample of all patients diagnosed with systemic JIA was obtained, and hyaluronic acid levels were determined from frozen sera samples. Demographic data, data on medication and laboratory data on inflammatory parameters (C-reactive protein, ESR, S100A8/A9 and S100A12) from the time points the serum samples were obtained were extracted from the AIDnet database. A

${ }^{1}$ German Center for Pediatric and Adolescent Rheumatology, GarmischPartenkirchen, Germany

Full list of author information is available at the end of the article retrospective chart survey was used to determine systemic inflammatory activity and arthritis activity. Patients were deemed to have systemic activity if they had fever and at least one other symptom according to the ILAR criteria at time of obtaining the sample, and were deemed to have active arthritis if they had at least one swollen joint or tenderness and limitation of motion at time of obtaining the sample. Univariate analysis was performed using descriptive statistics, Student's T-test and the Pearson correlation coefficient.

\section{Results}

25 patients were included in the study, of which 13 had active arthritis and 3 active systemic symptoms at time of sampling. $48 \%$ were treated with prednisone, $76 \%$ with a DMARD and $72 \%$ with a biologic drug at time of sampling. Patients with systemic symptoms had a mean level of hyaluronic acid of $61.0 \mu \mathrm{g} / \mathrm{l}$, compared to 134.5 $\mu \mathrm{g} / \mathrm{l}$ in patients with no systemic symptoms $(\mathrm{p}=0.330)$. However, patients with active arthritis had a mean level of hyaluronic acid of $180.5 \mu \mathrm{g} / \mathrm{l}$, compared to 48.1 $\mathrm{mg} / \mathrm{l}$ in patients without active arthritis $(\mathrm{p}=0.002)$. No significant correlations were found between levels of hyaluronic acid and levels of CRP, ESR, S100A8/A9 and S100A12.

\section{Conclusion}

In this Caucasian population, hyaluronic acid levels are correlated with clinical arthritis, but not with systemic activity or inflammatory parameters in systemic juvenile idiopathic arthritis. Hyaluronic acid does not appear to be a driver of systemic inflammation in sJIA.

\section{Disclosure of interest}

None declared. 


\section{Authors' details}

${ }^{1}$ German Center for Pediatric and Adolescent Rheumatology, Garmisch-

Partenkirchen, Germany. ${ }^{2}$ Medical Biochemistry and Microbiology, Science for

Life Laboratory, Uppsala University, Uppsala, Sweden. ${ }^{3}$ Internal Medicine,

University Hospital Erlangen, Erlangen, Germany.

Published: 5 December 2013

doi:10.1186/1546-0096-11-S2-P44

Cite this article as: Hugle et al.: PReS-FINAL-2031: Hyaluronic acid is a

marker of active arthritis, but not systemic inflammation in systemic

juvenile idiopathic arthritis. Pediatric Rheumatology 2013 11(Suppl 2):P44.

Submit your next manuscript to BioMed Central and take full advantage of:

- Convenient online submission

- Thorough peer review

- No space constraints or color figure charges

- Immediate publication on acceptance

- Inclusion in PubMed, CAS, Scopus and Google Scholar

- Research which is freely available for redistribution

Submit your manuscript at www.biomedcentral.com/submit
Ciomed Central 